\title{
HOW AND WHY ISLAMOPHOBIA IS TIED TO ENGLISH NATIONALISM BUT NOT TO SCOTTISH NATIONALISM
}

\section{Asifa Hussain and William Miller University of Glasgow}

\begin{abstract}
Muslim minorities throughout Europe are under threat of collateral damage from the Blair/Bush 'War on Terror.' In Scotland they also have to cope with the added possibility that Scottish nationalism might develop an 'ethnic' as well as a 'civic' dimension. But is Scottish nationalism part of the problem or part of the solution? Paradoxically, Muslims are under less pressure in Scotland than in England, despite Scotland's move over recent decades-psychologically as well as institutionally-towards nationalism.
\end{abstract}

The aim of this paper is to explore the connections between Islamophobia and sub-state nationalism within Britain. Muslim minorities in Britain and throughout Europe are now under threat of collateral damage from the Blair/Bush 'War on Terror.' But within Scotland, traditional Scottish self-consciousness, the long debate over devolution, rising nationalism and the eventual creation of a Scottish Parliament (inaugurated in 1999) all pose a potentially additional challenge to Scotland's Muslims.

In England there is a great deal of evidence to suggest that racial and cultural minorities identify with (inclusive) 'Britain' rather than (exclusive) 'England.' Ethnic minorities within England are notably reluctant to describe themselves as 'English' 
rather than 'British,' their modal preference being 'equally British and ethnic-group'-implying, it is claimed, that 'Britishness' is 'inclusive.' And conversely there is evidence to suggest that English nationalists-those members of the white majority in England who describe themselves as 'English, not British'-are particularly antagonistic towards racial and cultural minorities. If race, culture, and identity were linked together in a similar way within Scotland, we might expect that the position of any racially and culturally distinctive minority might have been undermined by the growth of Scottish nationalism-even without the added shock of Sept 11 th.

Paradoxically our research shows that in almost every particular the opposite is the case. It shows that Muslims in Scotland identify with Scotland rather than the supposedly more 'inclusive' Britain; that the Blair/Bush 'War on Terror' has committed Muslims far more strongly to Scotland than ever before; that despite (or perhaps because of) the growth of Scottish national identity and the advent of a separate Scottish Parliament, Islamophobia is significantly lower in Scotland than in England; that although Islamophobia is clearly tied to English nationalism within England, it is almost uncorrelated with Scottish nationalism within Scotland.

This may imply that English nationalism is more 'ethnic' while Scottish nationalism is more self-consciously 'civic.' But Scottish nationalism does have an impact on phobias within Scotland, though on Anglophobia far more than on Islamophobia. The tendency of Scots to define themselves negatively as 'not-English' may provide some shelter for other 'nonEnglish' groups within Scotland. Scottish Muslims gain some advantage from being a 'double-minority' - a minority within a minority.

But the relative weakness of all anti-minority ethnic phobias in Scotland also reflects the consistently multi-cultural strategy of Scottish political elites--critically including the independenceoriented leadership of the SNP (Scottish National Party) as well as the merely devolution-oriented Labour and Liberal-Democrat elites. The Scottish public is not so naturally multi-culturalist as these elites. But Scottish elites work harder to moderate public prejudice than do English elites. So at the elite level there is a 
coalition of Muslims and Scottish Nationalists, which has been strengthened by a common antagonism towards Blair and his international policies. That elite coalition does not reach down to the street, but it has sufficient influence on the street to control and moderate the street-level antipathy between Muslims and nationalists-of the kind that exists within England.

\section{Minorities in Scotland and England}

The largest racially and culturally distinctive minority in Scotland consists of ethnic Pakistanis. But the numbers of 'visible' ethnic minorities in Scotland are low. According to the 2001 Census ethnic Pakistanis (almost all of them Muslim) constitute less than one percent of the population. And altogether the 2001 Census shows that Muslims as-a-whole constitute just over one percent in Scotland.

Nonetheless Pakistani Muslims in Scotland are 'visible' unlike for example the very much larger English minority (defined by birth) in Scotland. And the Muslim Pakistanis are particularly visible because they are concentrated in the Glasgow area of west-central Scotland where one of them represents the Govan constituency in the British Parliament.

In England 'visible' ethnic minorities are more numerous and Carribeans, Africans, Indians, and others constitute a larger share. According to the 2001 Census there are just over one percent Pakistanis but slightly over three percent Muslim in England. Again the Asian minority are more visible than their numbers might suggest because they are concentrated in particular industrial areas of the North and Midlands of England.

\section{Scottish Muslims feel Scotland is a relatively safe-haven}

As part of a wider survey of minorities in post-Devolution Scotland we carried out six focus-group discussions with (selfdescribed) 'ethnic Pakistanis' in late 2002 followed by 759 telephone interviews with ethnic Pakistanis in 2003. Using a multilingual research team we were able to encourage both focusgroup participants and survey respondents to use English, Urdu or Punjabi (or any mixture of these languages) as they preferred. In the focus-group discussions we asked participants specifically about Sept 11 th and its impact on their lives in the intervening 
year. Sept 11th had been as traumatic for Muslims as for Americans, and a year later their memories of the time were still sharp.

There was shock, disbelief and some shame: 'shock... horrified ...numbness'[PK4-E]; 'unbelievable' [PK6-G]; 'ashamed that Muslims could be involved in this crime' $[P K 5-B]$, 'it upset me that my faith was being used'[PK4-E]. But there was also some resentment: 'They seem to associate terrorism only with Muslim countries'[PK2-A]; 'Look at what is happening in Ireland, Belfast' [PK2-B]; 'If someone is going to carry out an act of terrorism, they don't need to be a Muslim... there are all sorts of factions around the world representing different ideologies' [PK4E]. And fear. Fear of an anti-Muslim backlash: 'My mum and dad said don't walk outside the house with a headscarf... someone will shoot you or something, kill you on the street... It was scary... very scary' [PK1-G]. But also fear of terrorists: 'Terrorism can happen anywhere'[PK4-D]; 'We saw Pan Am crashing in Scotland'[PK4-E].

British people had become 'more unfriendly' towards Pakistanis and Muslims: 'It has made a difference... people look at us with suspicion'[PK4-D]; 'I heard of many physical attacks made against Muslims... my husband warned me not to go to the Mosque after Sept 11 th' [PK5-E]; 'I blame the media' [PK6-F].

But amongst participants in our Scottish Muslim focus groups direct personal experience of greater anti-Muslim attitudes in the aftermath of Sept 11th was limited in scope and intensity: 'Not really directly but people can be cold, you can detect the antiMuslim feeling' [PK5-A]; 'Some people may say that we are imagining anti-Muslim feeling, but we are not; we can feel it'[PK4-E]; 'racist looks'[PK2-B]; 'cold stares... worse in the early days after the attacks' [PK2-A]; 'I have been called Osama Bin Laden a couple of times' $[\mathrm{PK} 3-\mathrm{E}]$.

There was some disagreement about whether Scots in particular (as distinct from other Britons) had become more unfriendly towards Pakistanis and Muslims after Sept 11th: 'I don't think there have been any great differences between Scotland and England'[PK3-D]; 'It affected everybody in Scotland and in England' $[$ PK3-E].

But most thought the problem had not been so bad in 
Scotland as in England: 'I don't think there were too many problems in Scotland'[PK5-G]; 'It was only natural to have some problem here but it could have been much worse' [PK5-A]. There was: 'more trouble in England'[PK4-A]; 'a lot of trouble in England'[PK2-D]; 'a lot more racism in England' [PK1-E]; 'more organised groups in England which cause trouble against ethnic minorities'[PK1-C]; 'The National Front party [now called the BNP British National Party] has always been very popular in England' [PK2-A].

A few felt nowhere was safe in the aftermath of Sept 11th: 'After Sept 11th no place in the world felt safe' [PK5-E]; 'If this horrible thing had happened in Britain, I really don't know how people would react here...no place is really safe' $[\mathrm{PK} 2-\mathrm{C}]$. But for a variety of reasons, including both fear of anti-Muslim reactions and fear of terrorism, most were glad to be living in Scotland rather than in England or anywhere else. To them Scotland for all its faults seemed to be a relatively safe-haven in a very dangerous post-9/11 world: 'I was glad to be living in Scotland'[PK6-G]; 'much safer in Scotland'[PK6-D]; 'Scotland was a more comforting place to be than any other part of Britain' [PK2-B]; 'most safe in Scotland... if we were in Pakistan or America, we might have been accused and attacked'[PK3-C]; 'Living in France would be bad at the time and Holland would be quite bad as well...I wouldn't like to be in America at the time' [PK1-C]; 'It is safer being in Scotland than in Pakistan' [PK5D]; 'Even when the IRA were bombing, they never came to Scotland. It was always Manchester or London that got attacked'[PK6-C]. It is quite a list. It seemed safer to be in Scotland than in England, Europe, America - or Pakistan.

At the outset we hypothesised that Scottish self-consciousness, the long debate over devolution, and the eventual creation of a Scottish Parliament after the 1997 Referendum could have posed an added challenge to Muslims in Scotland. So in the focus-group discussions we asked participants to compare the impact of Scottish nationalism, culminating in the creation of a Scottish Parliament with the impact of Sept 11 th on Scottish attitudes towards Muslims. Both could have encouraged antiMuslim feelings.

The response of focus-group participants was unequivocal - 
not only was the Scottish Parliament less of a problem, it was in their view part of the solution. Some even found our question shocking: 'You cannot compare Sept 11th and the Scottish Parliament in the same way lexpressed in shocked manner]'[PK5-D with agreement from rest of group]; 'Sept 11 th was a lot worse... and I do not think the Scottish Parliament has been a negative thing'[PK1-D]; 'The only person [adversely] affected by the making of the Scottish Parliament is Tony [Blair]. Every ethnic minority is fine [i.e. happy] with the Parliament in Scotland'[PK2-B]; 'There was a peace statement made in the [Glasgow] City Chambers from all the faiths wanting to work together and overcome the difficulties. The will is there [in Scotland] to improve things' [PK4-E].

The only criticisms directed at the Scottish Parliament concerned its lack of power, authority, influence, or effectiveness: 'I am glad to be in Scotland, but there is a question about what the Scottish Parliament can do'[PK1-D]; 'Foreign policy is dealt with by [British] Central Government; the Scottish Parliament has got nothing to do with it' $[$ PK6-E].

The attitudes expressed in these focus-group discussions were corroborated by our large sample survey. We asked Scottish Pakistanis about their perceptions of conflict between Muslims and non-Muslims-in Scotland, in England, and 'across the world'. Although considerable numbers of Scottish Pakistanis (39 percent) do rate conflict between Muslims and non-Muslims in Scotland as at least 'fairly serious,' almost twice as many Scottish Pakistanis (77 percent) believe such conflict is 'fairly serious' south of the border in England. And 93 percent of them believe such conflict is 'fairly serious' around the world.

At far lower levels, there is an even more striking variation in Scottish Pakistanis' perceptions of 'very serious' conflict. Only six percent think conflict with non-Muslims in Scotland as 'very serious.' But 32 percent believe it to be 'very serious' in England, and 68 percent feel it is 'very serious around the world'. They may be wrong of course, but looking out from their Scottish vantage-point, Scottish Muslims see Scotland as a relatively (if only relatively) safe-haven. 


\section{A coalition of Muslims and (Scottish) Nationalists?}

The Muslim perception of Scotland as a relatively safe haven is at least plausible. Scottish political elites, both devolutionists and the more independence-minded nationalists, have consistently proclaimed a non-ethnic, inclusive, 'civic' concept of nationalism. With the possible exception of the Conservatives all significant political elites represented in the Scottish Parliament have taken an unambiguous and self-consciously multiculturalist position.

In particular the 'First Minister' [head of government] in the Scottish Parliament, Labour's Jack McConnell, has declared that Scotland needs more immigrants, asylum seekers and ethnic minorities. On the opposition side, the SNP (Scottish National Party) leader John Swinney has accused Labour of 'racism' in its ill-treatment of Muslim asylum seekers, repeatedly describing it as a 'national shame' or a 'national disgrace'-despite the fact that a large majority of Scots favour detaining asylum-seekers. For the SNP this is a courageously and in narrow short-term party-political terms costly position.

Conversely Muslim Pakistanis readily identify with Scotland while asserting their own culture and traditions and paying scant regard to traditional Scottish culture. Their Scotland, like the SNP's, is 'Scotland Future' not 'Scotland Past.'

In our survey of ethnic Pakistanis in Scotland we asked them to place themselves on the standard 5-point Moreno identity scale that runs from exclusively Scottish to exclusively British. Very few refused. But when faced with this forced choice between British and sub-British identities, Pakistanis in Scotland-unlike their counterparts in England-reject British identity. Even amongst those Pakistanis now living in Scotland who were born outside Scotland, three times as many describe themselves as 'mainly or exclusively' Scottish as opt for 'mainly or exclusively' British.

Of course, that is partly because their primary identity is 'Muslim' rather than any territorial identity-be that Scottish, British or Pakistani. Nonetheless insofar as ethnic Pakistanis in Scotland have a territorial identity (and they do, even if it is secondary) it is overwhelmingly 'Scottish'.

And this is matched by their constitutional and party prefer- 
ences. They now support Scottish independence far more than average Scot. And in terms of voting Pakistanis in Scotland swung decisively towards the SNP (Scottish National Party) at the 2003 Scottish Parliament elections so much so that by 2003 Pakistanis in Scotland were over twice as likely as the average Scot to vote for the Scottish National Party.

No doubt they were responding to the SNP's line on the Iraq war, which the SNP opposed at the 2003 Scottish Parliament election (and intend to make the centre-piece of their campaign for the 2004 Euro-election). Various Muslim groups, including the Lothian Muslim Voting Committeeand the Muslim Association of Britain called upon Muslims to switch to the SNP in 2003; and the SNP had long ago set up an affiliated organisation 'Asians for Independence.' The Nationalist welcoming committee already existed: all it needed was an event that could loosen Asians' traditional ties to Labour.

But whatever the reason, the significant point is that this racially and culturally distinctive minority is not alienated from the party of Scottish nationalism (small ' $n$ ' or large ' $N$ ') but actually far more favourable to it than the average Scot! Setting aside the BNP (the extreme right-wing British National Party which is far too easy a target), it is almost inconceivable that any English National Party, however moderate, could win twice as much support from Blacks and Asians as from the average voter in England.

\section{But are Scottish Muslims right? Is Scotland really a rela- tively safe haven?}

Scottish Muslims are clearly attached to the inherently plausible view that Scotland is a relatively safe haven - even in comparison with neighbouring England. But they might nonetheless be wrong: it might be merely an outsider's perspective. Perhaps England and the English are not so bad as they look from the outside. One test is to look at the perceptions of the majorities in England and Scotland. How do they rate the level of conflict with their own Muslim minorities?

We use a tight definition of 'majorities' in England and Scotland. Not surprisingly Islamophobia (and in Scotland Anglophobia also) is lower amongst the minorities than amongst 


\section{Ethnic Studies Review Volume 27: 1}

the titular majorities, and it would be misleading to include the views of the minorities themselves in our calculations of antiminority-phobias.

We define 'majority England' or the 'majority English' as 'White,' non-Muslims, living in England. And 'majority Scotland' or 'majority Scots' even more tightly as 'White', non-Muslims, born in Scotland, with Scottish-born partners (if any). It is important to exclude English immigrants in Scotland because they are (proportionately) so numerous and so distinctive. It is unnecessary to exclude Scottish immigrants in England because they are neither (proportionately) numerous nor distinctive. This asymmetry is a consequence of the fact that the population of England is ten times that of Scotland.

The perceptions of 'majority Scots' and 'majority English' suggest that conflict with Muslims is indeed much greater in England than in Scotland. Only 42 percent of majority Scots think Muslim/non-Muslim conflict is at least 'fairly serious' in Scotland. But 61 percent of the majority English think Muslim/non-Muslim conflict in England is at least 'fairly serious.' That suggests Scottish Muslims are indeed correct in their view that Scotland is a relatively safe haven. A significantly greater number of the English feel in conflict with Muslims.

\section{Why is Scotland a relatively safe haven? Better Muslims or better Scots?}

It does not take two to make a conflict however. One is enough. Perhaps conflict with Muslims is greater in England because Muslims themselves are different there. The numbers are different. There are more Muslims in England - though still only three percent. Or perhaps Muslims in England are socially different. One Muslim participant in a Scottish focus group claimed that 'Asian people in Scotland are more productive than Asian people living in England. You get a lot of Asians in England that are uneducated, unemployed and involved in crime. In Scotland Asian people make something of themselves, in England maybe not' $[$ PK6-E]. Or perhaps Muslims in England lead more segregated lives. The same focus-group participant continued: 'In Oldham [England] there were riots. One side of the town is totally White while the other side is totally Asian. The Asians there [in 
Oldham] are the scum of the earth... nothing to do but watch television all day, so they are out causing riots'[PK6-E]. And another agreed more diplomatically: 'It is better to live in a mixed area than to be segregated' [PK6-G].

But another possibility is that conflict is greater in England because the English are different from the Scots. If the people of England are more Islamophobic than the Scots then Scottish Muslims' perception of Scotland as a relatively safe-haven would owe something to Scotland and to majority Scots, irrespective of any differences between Muslims themselves. We can test that directly. We use five strictly comparable indicators of Islamophobia in England and Scotland:

M1: feeling that Muslims 'take jobs, housing and health care from other people in Britain/Scotland'

M2: feeling that Muslims 'could never be really committed to Britain/Scotland'

M3: feeling that Muslims 'are more loyal to other Muslims around the world' than they are to 'other people in this country'

M4: feeling that 'England/Scotland would begin to lose its identity' if more Muslims came to live in England/Scotland'

M5: saying they 'would feel unhappy if a close relative married or formed a long-term relationship with a Muslim'

Following familiar English usage, some of these questions in England use the term 'Britain' instead of 'England.' In Scotland they use the term 'Scotland' without exception. These five questions provide a comparative index of Islamophobia in England and Scotland.

In addition within Scotland we repeated these five questions but re-wording them to focus on English immigrants rather than Muslims:

E1: feeling that English immigrants 'take jobs, housing and health care from other people in Scotland'

E2: feeling that English immigrants 'could never be really committed to Scotland'

E3: feeling that the English immigrants 'are more loyal to England' than they are to Scotland 


\section{Ethnic Studies Review Volume 27: 1}

E4: feeling that 'Scotland would begin to lose its identity' if more English immigrants came to live in Scotland E5: saying they 'would feel unhappy if a close relative married or formed a long-term relationship with an English person now living in Scotland'

These five questions provide a strictly comparative index of Islamophobia and Anglophobia within Scotland.

Beyond that we have one indicator that applies only to Muslims: M6: feeling that 'Muslims living in Britain have not done a great deal to condemn Islamic terrorism' And there are indicators of anti-minority-phobia that do not specify either Muslims or English immigrants explicitly, though some may apply more to one than the other:

P1: feel that 'to be truly British you have to have been born in Britain'

P2: feel that 'to be truly English/Scottish you have to have been born in England/Scotland'

P3: feel that 'to be truly British you have to be White rather than Black or Asian'

P4: feel that 'to be truly English/Scottish you have to be White - rather than Black or Asian'

Large numbers insist that birthplace is an important criterion for nationality and relatively few stress race. But there is no significant difference between Scotland and England in the extent to which the majority feel it is necessary to be born in the country in order to be 'truly' British, 'truly' Scottish, or 'truly' English, and only a small difference between Scotland and England in the extent to which the majority feel it is necessary to be White in order to be 'truly' British, Scottish or English. In these respects attitudes in England are only very slightly more racist than in Scotland if at all.

But very consistently across a whole range of issues from economic resentment and nationalist distrust to fears of threats to national identity and especially social exclusion, Islamophobia is greater in England than in Scotland. We should not overstate the extent of Islamophobia. Our more detailed SSAS data show that majority Scots overwhelmingly support cultural variety. They overwhelmingly support laws to ban discrimination against Muslims (race discrimination has long been illegal in Britain, but 
religious discrimination has not), and they are sensitive to the lack of any Muslim or Asian MSPs in the Scottish Parliament. Nonetheless around a third of majority Scots feel some economic resentment towards Muslims and express socially exclusive attitudes towards them. Many feel Scotland would begin to lose its identity if more Muslims came to live in Scotland. Many doubt Muslims' commitment to Scotland. And most Scots feel Muslims' first loyalty lies outside Scotland.

On most but not all of these points majority Scots are rather more Islamophobic than Anglophobic though most of them doubt the loyalty 'to Scotland' of both the Muslims and English immigrants. And while almost a fifth of majority Scots feel a person has to be 'White' to be a 'true Scot,' two-thirds feel they would have to be born in Scotland (implicitly excluding the English immigrants but not the Scots-born Muslims). In the event of independence one third would withhold Scottish passports from those they felt were not 'true Scots.'

So without overstating the degree or intensity of Islamophobia or Anglophobia in Scotland, we have clear evidence that both phobias exist. We also have clear evidence that Islamophobia is greater in England than in Scotland.

Excluding those with no opinion or mixed opinions, an average of 63 percent of the majority in England agree with M15 (i.e. Islamophobia in England $=63 \%$ ). By contrast only an average of 49 percent of majority Scots agree with M1-5 (i.e. Islamophobia in Scotland $=49 \%$ ). An average of 38 percent of majority Scots agree with E1-5 (i.e. Anglophobia in Scotland = $38 \%$ ). So on strictly comparable indicators Islamophobia in England runs 14 percent ahead of Islamophobia in Scotland, and as a measure of its political significance we note that this difference is greater than the difference between Islamophobia and Anglophobia within Scotland.

Only five percent of Scots would be unhappy if a close relative 'married or formed a long term relationship' with an English immigrant, but 32 percent of majority Scots and 52 percent of the majority in England would be unhappy if a close relative 'married or formed a long term relationship' with a Muslim.

So very few feel socially exclusive towards the English, but a third of Scots and half the English feel socially exclusive towards 
Ethnic Studies Review Volume 27: 1

\section{Table 2: Impact on phobias of knowledge about Muslims}

\begin{tabular}{|c|c|c|c|c|}
\hline & $\begin{array}{r}\text { at least } \\
\text { quite a lot }\end{array}$ & $\begin{array}{r}\text { not very } \\
\text { much }\end{array}$ & $\begin{array}{r}\text { nothing at } \\
\text { all }\end{array}$ & impac \\
\hline & $\%$ & $\%$ & $\%$ & ? \\
\hline Anglophobia: average El-5 & 33 & 35 & 47 & 14 \\
\hline Islamophobia: average M1-5 & $41[51]$ & $44[60]$ & $66[78]$ & $24[27$ \\
\hline Muslims not condemn terror & $46[59]$ & $55[62]$ & $64[73]$ & $18[14$ \\
\hline \multicolumn{5}{|c|}{ 'o be 'truly' British / English / Scottish must be: } \\
\hline ...born in Britain & $58[53]$ & $64[63]$ & $78[81]$ & $20[28$ \\
\hline ...born in Scotland/England & $55[50]$ & $61[62]$ & $77[78]$ & $22[28$ \\
\hline White (to be British) & $13[17]$ & $12[15]$ & $24[36]$ & $11[19$ \\
\hline White (to be Scottish/English) & $12[18]$ & $14[20]$ & $31[38]$ & $19[26$ \\
\hline
\end{tabular}

Jotes: \% outside brackets are for Scotland; \% inside [ ] are for England.

JK's \& undecided excluded from calculation of percentages. Source: SSAS/BSAS 2003.

Muslims. The difference, however, between Scots and English attitudes towards Muslims is striking, and any suspicions that answers to this question are affected by political correctness cannot explain why the responses are so very different in Scotland and England. Indeed the intensity of happiness and unhappiness varies between Scotland and England: 26 percent of majority Scots but only half as many majority English go far beyond political correctness and claim they would actually be 'very happy' to have a Muslim relative.

By common agreement, whether viewed from inside or outside England, there is more perceived Muslim/non-Muslim conflict in England, and that is linked, whether as cause or effect or both, to greater Islamophobia in England. 


\section{How strong is the connection between Islamophobia and sub-state nationalism?}

The usual explanation of racist or ethnic phobias is simply 'small-mindedness,' parochialism rather than cosmopolitanism, brought on by living a physically, intellectually, or emotionally restricted life.

Social background can affect parochialism. Lack of education, especially lack of higher education, is a key variable underlying parochialism. Generation rather than age itself also could be significant since the development of mass media and cheap mass transport have globalised the world of the average person to an unprecedented degree. Globalisation may have eroded differences between the educated and uneducated even as (higher) education itself has become more widespread. By contrast globalisation may intensify class divisions: the working class operating in a relatively local employment market and engaged in relatively routine activities are not only likely to have restricted parochial outlooks but are more exposed to economic competition from immigrants and incomers whether these come from other cultures or not. Gender plays a potentially significant but ambiguous role since women have traditionally (but perhaps no longer) had more parochial perspectives yet at the same time a more sympathetic outlook.

Both Scotland and England have National Churches 'Established' by law, the (Presbyterian) Church of Scotland and the (Episcopalian) Church of England. Their connection with the state is now relatively weak and indeed obscure but they remain, to some of their adherents at least, an expression of the nation. In both countries the public divides into only three large religious groups (plus many much smaller ones): the National Church ('C of $\mathrm{S}$,' or ' $\mathrm{C}$ of $\mathrm{E}$ '), Catholics, and most numerous of all, the irreligious. It seems reasonable to ask whether adherents of the national church take a distinctive view of Muslims (and within Scotland, of English immigrants also).

But whatever its social foundations, parochial nationalism goes naturally with racist and ethnic phobias. 'Multicultural nationalism' is an oxymoron. Despite the conscious efforts of political elites in Scotland including the leaders of the SNP (Scottish National Party) there is an inescapable tension between 


\section{Ethnic Studies Review Volume 27: 1}

nationalism and multiculturalism and a historic tendency for them to prove incompatible. Pulzer argues that nationalism is often 'inspired... by the urge to emancipate' but that its 'logical conclusion' is very different: 'a paroxysm of destructiveness.' The genuinely inclusive 'civic' nationalism of the Scottish political elite may not apply down 'at street level.' And in England there are no equivalent 'civic' English nationalists, no leaders of an English National Party with a multiculturalist agenda. So in England the natural connection between parochial nationalism and anti-minority-phobias is not consciously restrained by a 'civic' nationalist political elite. It seems essential therefore to investigate the connection between 'street-level' nationalism and racial or ethnic phobias and with the expectation that the connection will prove stronger in England than in Scotland.

Tabulating the attitudes of majorities towards minorities by personal contacts and knowledge, class, education, age and generation, gender, religion, nationalism, and partisanship suggests that education is more important than class, that gender and religious sect (Established 'national' church versus Catholics) have no impact, and that the impact of religiosity merely reflects the generational decline in religiosity a generational rather than truly religous impact. So we focus on just five key factors: (i) contacts and knowledge, (ii) age and generation, (iii) education, (iv) national identity, and (v) partisanship or 'political nationalism.'

\section{The impact of contacts and knowledge}

Compared to those who say they know at least 'quite a lot' about Muslims, those who say they 'know nothing at all' are around 25 percent more Islamophobic (24 percent more in Scotland and 27 percent more in England). In Scotland, the 'know nothings' are also 14 percent more Anglophobic as well. The 'know nothings' are also around 16 percent more likely to criticise Muslims for not sufficiently condemning terrorism, around 20 percent more likely to cite being 'White' as a necessary condition for being 'truly' English or Scottish, and up to 28 percent more likely to cite being born in the country as a necessary condition for being 'truly' English or British (rather less so in Scotland however). 
Hussain and Miller-Islamophobia

\section{Table 2: Impact on phobias of knowledge about Muslions}

\begin{tabular}{|c|c|c|c|}
\hline & $\begin{array}{l}\text { at lear } \\
\text { gure } 2 \text { bo }\end{array}$ & $\begin{array}{l}\text { nod very } \\
\text { moveth }\end{array}$ & $\begin{array}{r}\operatorname{coseng} x \\
\text { in }\end{array}$ \\
\hline & 9 & 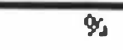 & $\overline{8}$ \\
\hline Anduptioter average [I]-S & 33 & 35 & 4T \\
\hline Istamoptwas: averes MJ.S & 4) [S]] & $44[\infty]$ & 86 (T8) \\
\hline Musabus not condem de erox & $46[59]$ & $\operatorname{ss}\left[\theta_{2}\right]$ & $G_{4}\left[T_{3}\right]$ \\
\hline
\end{tabular}

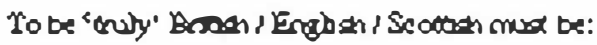

\begin{tabular}{|c|c|c|c|}
\hline ...Domin Bxton & $58[53]$ & $\& 4[9]$ & $\pi 8(8)]$ \\
\hline ... bon n Samond Endand & $\mathrm{ss}[\mathrm{so}]$ & 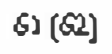 & $\pi[\pi /]$ \\
\hline Whate ( $\infty$ be $B \alpha x+1)$ & 3 3 [נד] & 32 [3S] & 24 [3G] \\
\hline Whate (10 be Scondw End $x+1]$ & $32[38]$ & $34[20]$ & $3)$ (38] \\
\hline
\end{tabular}

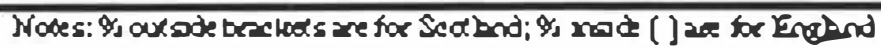

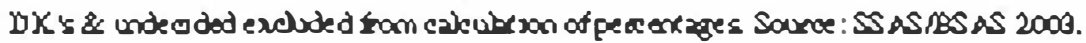

\section{The impact of age and generation}

Age and generation have a significant impact on Islamophobia in both England and Scotland (though very little impact on Anglophobia in Scotland). On both sides of the border our composite measure of Islamophobia varies by 20 percent across the age cohorts though age has more impact on simple racial acceptance in England than in Scotland, and on both sides of the border there is evidence of a sharp generational shift at about age 55, rather than a progressive impact of steadily increasing age.

By margins of 29 percent in England and 21 percent in Scotland, the old are more apprehensive than the young that Britain (or Scotland) would begin to lose its identity if there were an influx of Muslims. By margins of 30 percent in England and 24 percent in Scotland the old are more likely to feel that to be 


\section{Ethnic Studies Review Volume 27: 1}

'truly English (or Scottish)' a person must be White. By smaller margins of 23 percent in England and only 14 percent in Scotland, the old are more likely to feel that to be 'truly British' a person must be White - 'rather than Black or Asian'. And by huge margins of 55 percent in England and 48 percent in Scotland the old are more unhappy than the young at the thought of having a Muslim relative.

In Scotland all these indicators reveal a 'step effect' at around age 55 - a generational shift rather than a progressive age effect. And the same is true in England except on the question about a Muslim relative.

\section{The impact of education}

Comparing university graduates with those who have no educational qualifications it seems that education has more impact on Islamophobia (and on Anglophobia) than almost anything else.

From graduates down through levels of school qualifications Islamophobia (and Anglophobia) increase steadily. So by mar-

\section{Table 3: Impact on phobias of Age \& Generation}

$\begin{array}{lrrrrr} & \text { to } 34 & 45-44 & 45-54 & 55-64 \\ & & \% & \% & \% & \% \\ \text { Anglophobia: average E1-5 } & 35 & 39 & 37 & 39 \\ \text { Islamophobia: average M1-5 } & 42[56] & 46[59] & 45[58] & 55[64] \\ & & & & \\ \text { Muslims not condemn terтоr } & 55[63] & 62[69] & 51[57] & 55[57]\end{array}$

To be 'truly' British / English / Scottish must be:

$\begin{array}{rllll}\text {...bom in Britain } & 59[64] & 70[60] & 59[61] & 71[67] \\ \text {...bom in Scotland/England } & 59[62] & 65[59] & 60[57] & 70[69] \\ \text { White (to be British) } & 10[12] & 16[12] & 12[16] & 17[24] \\ \text { White (to be Scottish/English) } & 12[14] & 14[17] & 14[14] & 22[27]\end{array}$

Notes: \% outside brackets are for Scotland; \% inside [ ] are for England.

DK's \& undecided excluded from calculation of percentages. Source: SSAS/BSAS 2003. 
gins of 49 percent in England and 34 percent in Scotland those without qualifications are more Islamophobic than graduates. In Scotland they are also 25 percent more Anglophobic.

The pattern is very consistent but not quite monotonic: those with 'higher education below degree level' are slightly more Islamophobic (and Anglophobic) than those with the highest level of school qualifications.

Similarly, by margins ranging from 27 percent to 46 percent in England, and from 19 percent to 36 percent in Scotland, those without qualifications are more likely than graduates to cite race or birthplace as a necessary condition for being truly English/Scottish or British.

Only newspaper choice (closely linked in Britain to education) has a greater apparent impact on Islamophobia, and there the causal direction is ambiguous. English readers of the high-

\section{Table 4: Impact on phobias of Education}

\begin{tabular}{|c|c|c|c|c|}
\hline & Dearee & $\begin{array}{l}\text { ragthee } \\
\text { edx } \\
\text { bebow } \\
\text { degree }\end{array}$ & $\begin{array}{l}\text { Akwed } \\
\text { eguve }\end{array}$ & $\begin{array}{l}\text { O kewel } \\
\text { eguro }\end{array}$ \\
\hline & 8i, & 9 & 9 & \$s \\
\hline Arolophaton: aveoge EJ.S & 21 & 3s & 30 & 42 \\
\hline 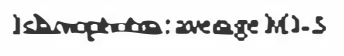 & $28(3)]$ & $44(5 \pi)$ & $38(s)]$ & $54(\infty)$ \\
\hline 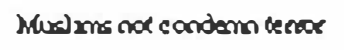 & $3 \&(4)]$ & so(w) & $\$[\&]$ & TO [\&T] \\
\hline
\end{tabular}

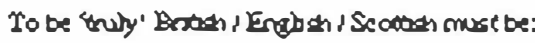

\begin{tabular}{|c|c|c|c|c|}
\hline ...ban $n$ Bran & 42 (3T) & \& 150$]$ & $\$(s s]$ & $\theta(\infty)$ \\
\hline 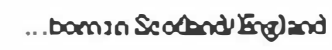 & 4) (34) & $\& 4(s)]$ & $\operatorname{ss}(53)$ & $\Leftrightarrow\left(T_{2}\right)$ \\
\hline 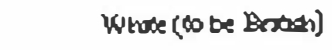 & $3(\theta)$ & $23(J 5)$ & $8(10)$ & $28(18)$ \\
\hline 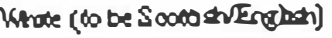 & $3(9)$ & $J T(J 4]$ & $8[23]$ & $39(24)$ \\
\hline
\end{tabular}

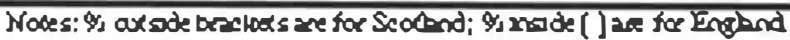

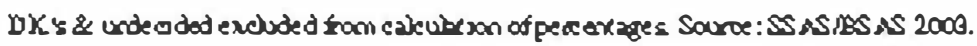




\section{Table 5: Impact on phobias of National Identity}

\begin{tabular}{|c|c|c|c|c|c|c|c|}
\hline & Excl & More & Equally & More & Excl & Comparative & Full English \\
\hline & Brit & Brit & E/S \& Brit & Engl/Scot & Engl/Scot & Impact & impact \\
\hline & $\# 1$ & $\# 2$ & $\# 3$ & $\# 4$ & \#5 & $\# 5-\# 3$ & $\# 5-\# 1$ \\
\hline & $\%$ & $\%$ & $\%$ & $\%$ & $\%$ & $\%$ & $\%$ \\
\hline Anglophobia: average El-5 & na & na & 33 & 35 & 46 & 13 & \\
\hline Islamophobia: average Ml-5 & na [50] & na [65] & $50[58]$ & $46[61]$ & $54[78]$ & $4[20]$ & [28] \\
\hline
\end{tabular}

ติ

Muslims not condemn terror

$53[58]$

$49[62]$

$65[72]$

12 [14]

[20]

To be 'truly' British / English / Scottish must bc:

$\begin{array}{rccccccc}\text {...born in Britain } & \text { na [53] } & \text { na [55] } & 62[64] & 65[67] & 75[80] & 13[16] & \text { [22] } \\ \text {...born in Scotland/England } & \text { na [49] } & \text { na [60] } & 57[57] & 65[67] & 71[81] & 14[24] & \text { [32] } \\ \text { White (to be British) } & \text { na [9] } & \text { na [17] } & 16[11] & 14[21] & 18[38] & 2[27] & {[29]} \\ \text { Whitc (to bc Scottish/English) } & \text { na [14] } & \text { na [22] } & 17[14] & 19[24] & 21[44] & 4[30] & {[30]}\end{array}$

Notes: \% outside brackets are for Scotland; \% inside [ ] are for England.

DK's \& undecided excluded from calculation of percentages. Source: SSAS/BSAS 2003.

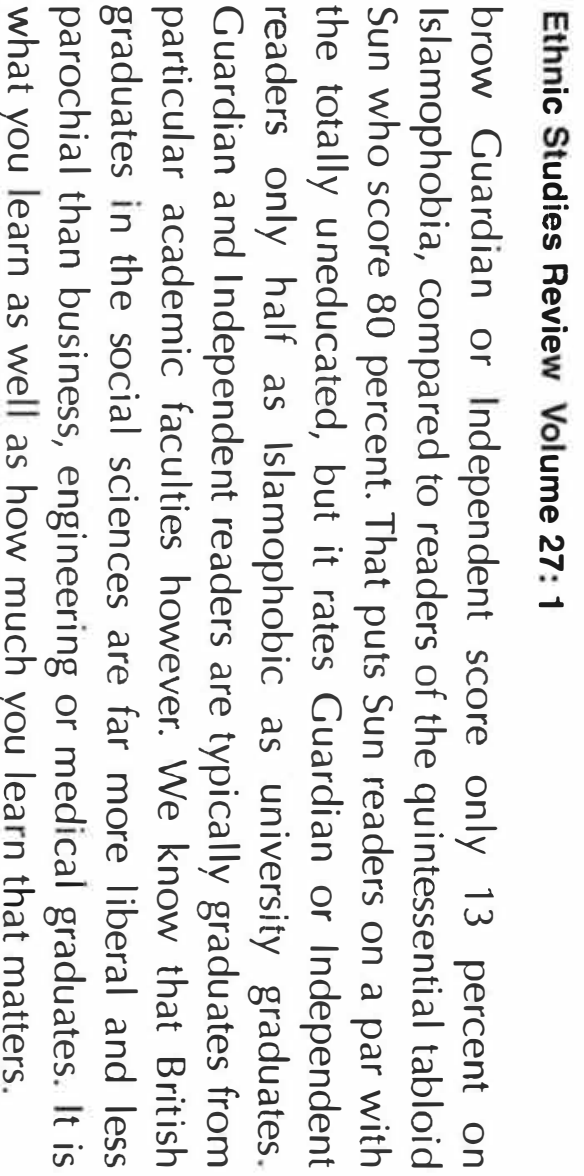




\section{The impact of sub-state national identities}

One measure of national identity is provided by answers to the 'Moreno' question:

Which, if any, of the following best describes how you see yourself?

English/Scottish not British

More English/Scottish than British

Equally English/Scottish and British

More British than English/Scottish

British not English/Scottish

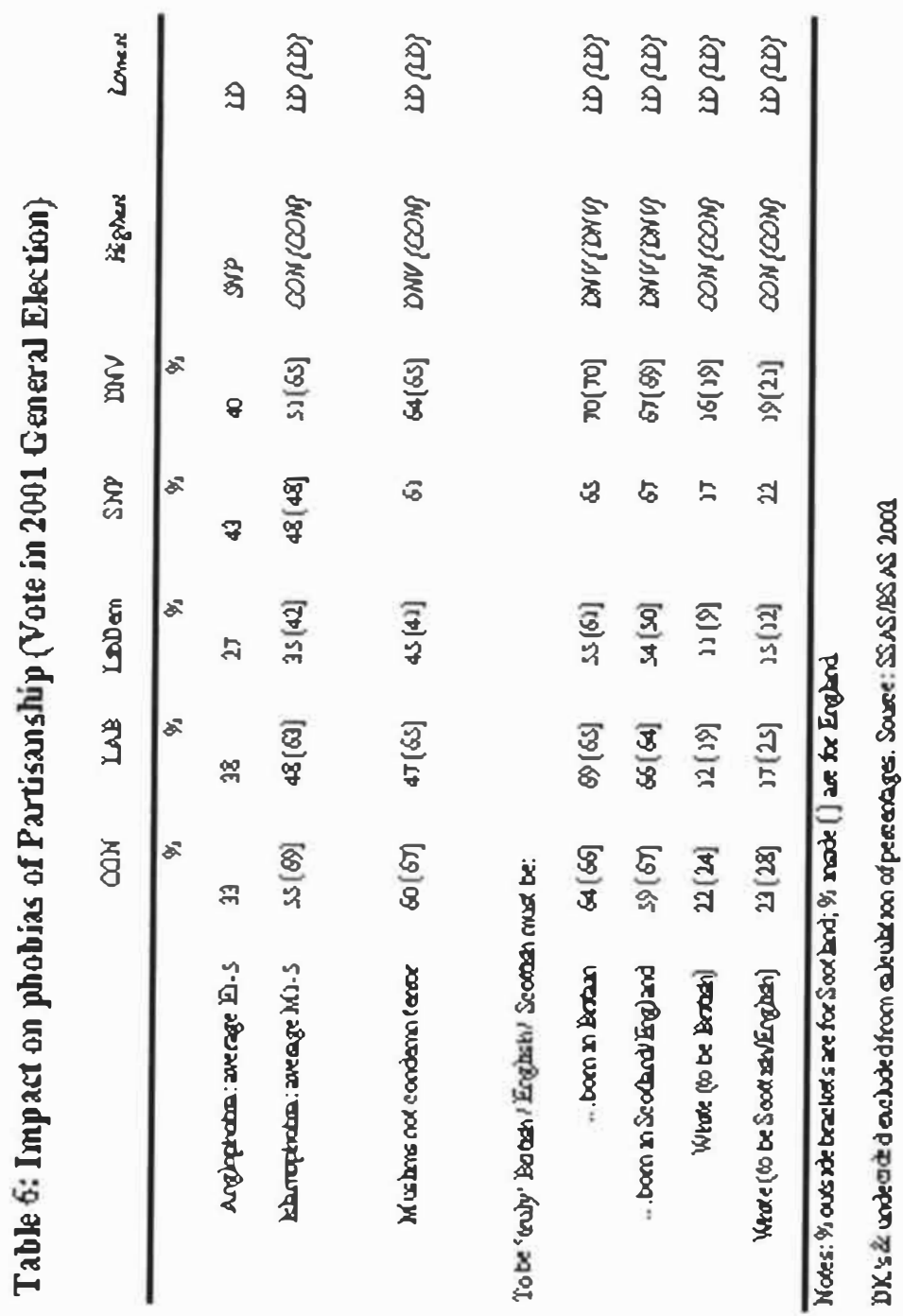


(The term 'English' is used for interviews within

England,

the term 'Scottish' for interviews within Scotland.)

In the 1980s the Moreno scale was originally conceived as a 5-point symmetric scale. But by 2003 only a quarter of majority English and less than three percent of majority Scots identified more with Britain than with England/Scotland. Identification 'more with Britain' was much more popular amongst the bulk of the minorities - including English immigrants in Scotland as well as Blacks and Asians in England (though Asians in Scotland identify very strongly with Scotland, not with Britain). The consequence is that the numbers in categories 4 and 5 (more British or exclusively British) are now too small to provide a basis for any analysis in Scotland and must be used with care even in England. Nearly all majority Scots and most majority English are spread across an effectively 3-point scale running from 'exclusively' English/Scottish through to 'equally British and English/Scottish' - that is on a scale that (effectively) runs from 'exclusive' to 'dual' identities.

Compared to dual identifiers, the exclusively English are 20 percent more Islamophobic. But the exclusively Scottish are only a negligible four percent more Islamophobic. Indeed exclusive national identity as measured by the Moreno scale of national identity makes people in Scotland more Anglophobic (by 13 percent) rather than more Islamophobic (a mere four percent). Furthermore, the majority English (unlike majority Scots) do spread themselves all the way across the full 5-point scale. So arguably the proper measure of the impact of parochial nationalism on Islamophobia in England is 28 percent rather than 20 percent - the difference between the exclusively English and the exclusively British in England, rather than between the exclusively English and those who are equally British and English. But by any measure parochial nationalism has a significant impact on Islamophobia in England - yet not in Scotland.

The contrast between the impact of parochial nationalism in England and Scotland is perhaps even greater when we assess its impact on citing race as a necessary condition for being truly English/Scottish or British. Compared to those who identify equally with Britain and England/Scotland, the exclusively 
English are 27-30 percent more likely to cite race (being 'White rather than Black or Asian') as a necessary condition for being 'truly British' or 'truly English'. In Scotland the exclusively Scottish are scarcely any more likely (only two to four percent) than those who identify equally with Britain and Scotland to cite race as a necessary condition for being 'truly British' or 'truly Scottish.'

Although its impact is not great, such as it is the impact of Scottish nationalism in complete contrast to English nationalism seems almost irrelevant to Islamophobia. Instead it is specifically Anglophobic, focused on the 'Auld Enemy,' the 'significant other' that helps to define Scottish identity, rather than on minorities that differ far more in terms of race, religion or culture from majority Scots.

\section{Political nationalism: the impact of partisanship}

Political nationalism, especially support for the SNP (Scottish National Party) can be measured by voting behaviour. We use the voting choices (and abstention) of majority English and majority Scots at the 2001 General Election. The only parties that had enough voters to provide a basis for analysis in England and Scotland are the Conservative, Labour, and LiberalDemocrat parties plus, in Scotland only, the SNP. (The extreme racist BNP, British National Party, won considerable publicity in England but very few votes.)

Taking the seven parties separately (e.g. distinguishing Conservative voters in Scotland from those in England) the level of Islamophobia is lowest of all amongst Scottish LiberalDemocrats (27 percent), and highest of all amongst English Conservatives (67 percent). They differ by a full 40 percent on Islamophobia.

Within each country, both Islamophobia and Anglophobia are lowest amongst Liberal-Democrats. But while Anglophobia is highest amongst SNP voters, Islamophobia is highest amongst Conservatives - both in England and also in Scotland.

Non-voters come a close second to SNP voters on Anglophobia in Scotland, and a close second to Conservatives on Islamophobia both in England and in Scotland. 


\section{Ethnic Studies Review Volume 27: 1}

\section{Conclusions}

In England there is a great deal of evidence to suggest that racial and cultural minorities identify with supposedly-inclusive 'Britain' rather than supposedly-exclusive 'England.' And conversely that exclusively English nationalists, those members of the White majority who describe themselves as 'English, not British', are particularly antagonistic towards racial and cultural minorities. If race, culture, and identity were linked together in a similar way within Scotland, we might expect that the position of any racially and culturally distinctive minority might have been undermined by the growth of Scottish nationalism even without the shock of Sept 11th But paradoxically we have shown that in almost every particular the opposite is the case. Our research shows that Muslims in Scotland identify with 'Scotland' rather than 'Britain' and the 'War on Terror' has committed Muslims far more strongly to Scotland than ever before.

It is a rational response. Despite or more probably because of the growth of Scottish national identity and the advent of a separate Scottish Parliament, Islamophobia is significantly lower in Scotland than in England.

Insofar as Scottish nationalism has an impact on ethnic-phobias, it has more impact on Anglophobia than on Islamophobia. So Islamophobia is not only significantly greater in England than in Scotland, it is also much more closely tied to English nationalism within England, than to Scottish nationalism within Scotland. That reflects the tendency of Scots to define themselves negatively as 'not-English' and to define the English as their 'Auld Enemy.' More important, it implies that English nationalism is more 'ethnic' while Scottish nationalism is more 'civic'.

There are other factors, notably age and education, that have more impact than nationalism on Islamophobia. We have focused on the impact of nationalism not because it is so great but because, especially in Scotland, it is so very weak. Like Sherlock Holmes, we have focused on the importance of 'the dog that did not bark', or as Peter Pulzer might say, 'the tiger that did not snarl.' The impacts of age and education are large but not unexpected, while the impact of nationalism in Scotland is unexpectedly small or even, by some criteria, the reverse of expectations. 
That reflects the consistently multi-cultural strategy of Scottish political elites - including the devolutionists of Scottish Labour, the federalists of Scottish Liberal Democrats, and especially the independence-oriented leadership of the SNP (Scottish National Party) who were determined that Scottish government and Scottish people should not only be more independent but more virtuous. They were minded to replace Gandhi's claim: 'Good government is no substitute for self-government' with its inverse: 'self-government is no substitute for good government' and add 'nor an excuse for self-indulgent citizens.' Hence SNP leader John Swinney's claim (cited above) that 'racism' is a 'national shame' or a 'national disgrace', a claim echoed in one of our Muslim focus-groups by the participant who asserted ' 90 percent of the people here are nice but the other ten percent are racist which is a shame for the image of Scotland'[PK3-D]. For these high-minded liberal elites, independence meant responsibility rather than freedom.

The Scottish public is not so naturally multi-culturalist as Scottish elites. We have evidence of a very slight tendency for the exclusively Scottish to be just a tad more Islamophobic as well as significantly more Anglophobic. But Scottish elites, critically including Scottish Nationalist elites, work harder to moderate public prejudice than do English elites, even English mainstream elites that make no claim to represent English nationalism. The Scottish Nationalist elite's multiculturalism does not reach down to the street, but it has sufficient influence on the street to control and moderate the street-level antipathy between Muslims and nationalists, of the kind that exists within England.

Consequently Muslims in Scotland are not mistaken when they conclude that Scotland, for all its acknowledged faults, its prejudice and its harassment of Muslims, is nonetheless a relatively safe-haven in a very dangerous world, the best place for them to be in the aftermath of Sept 11 th. 